\title{
Nevrastenisk impotens
}

Tidsskriftet har alltid ønsket å bringe leserne nytt fra internasjonale tidsskrifter. I 1909 var det referert en artikkel fra tidsskriftet Semaine medicale. Det dreide seg om et foredrag på den italienske indremedisinske kongressen sommeren 1909 (Tidsskr Nor Lægeforen 1909; 29: 1083).

\section{Colombo: Behandling av neurasthenia sexualis med Biers stase.}

Impotentia coeundi skyldes hos de aller fleste neurastenikere en antisuggestion, som har sit utgangspunkt fra et mislykket coitus. Dette gjør et vældig indtryk paa patienten, som nu tror at han lider av uhelbredelig impotens; ved hvert nyt forsøk bevirker skrækken, at alle hans anstrengelser blir frugtesløse.

Ofte kan en «intelligent» dame helbrede en patient av denne sort, men en saadan dame er sjelden. Patienten render til alle mulige læger og kvaksalvere, uten at det lykkes nogen av disse at overbevise patienten om hans mandbarhed. Hos flere individer av denne art og hvor impotensen utelukkende skyldes antisuggestion, har Colombo opnaat helbredelse ved hjælp av hva han kalder contre-suggestion materielle - d. v. s. ved at vise dem de facto, at deres penis kan præstere kraftige erektioner til trods for dens involuntære inhibition paa grund av skrækken.

Dette foregaar paa følgende maate: En glasrecipient av form som en penis og av saadanne dimensioner, at den kan rumme en erigeret penis, anbringes saaledes, at dens frie ende hermetisk omfatter pubisregionen. Man forbinder recipienten med en luftpumpe, som drives ved elektricitet og luften suges ut som ved Biers apparater. Idet luften forsigtig pumpes ut svulmer corpora cavernosa sterkt op, efter 30-40 sekunders forløp er erektionen fuldstændig - til patientens store forbauselse, gjennem glasrecipientens vægger kan han titte paa sit stadig svulmende membrum. Erektionen vedlikeholdes 2-3 minuter; naar der slippes luft ind, foregaar detumescensen gradvis.

Operationen gjentages 8-10 ganger hver anden dag, inntil patienten har faat sexuel selvtillit og paanyt spontane erektioner. Nu behøves ingen «intelligent» dame.

(Sem. Med. 1909, nr. 26). 